\title{
Review
}

\section{Co-infection leprosy and tuberculosis: a systematic review}

\author{
Luciana Cavalcante Trindade ${ }^{1}$, Micheline da Silveira Mendes ${ }^{2}$, Lourdes Conceição Martins ${ }^{3}$, Antônio \\ Carlos Evangelista de A Bonfim ${ }^{4}$, Fernando Luiz Affonso Fonseca ${ }^{1}$
}

\author{
${ }^{1}$ ABC Medical School, Stricto Sensu Postgraduate Program in Health Sciences, Santo André, SP, Brasil \\ ${ }^{2}$ Osvaldo Cruz Foundation Stricto Sensu Postgraduate Program in Public Health, Recife, PE, Brasil \\ ${ }^{3}$ Catholic University of Santos, Stricto Sensu Postgraduate Program in Public Health, Santos, SP, Brasil \\ ${ }^{4}$ Nova Esperança Medical School, Dermatology Medical Residency Program, João Pessoa, PB, Brasil
}

\begin{abstract}
Leprosy and tuberculosis are endemic in several countries. The aim of this study was to describe factors associated with co-infection among both diseases. A systematic review was carried out, following the Quality of Reporting of Meta-analyses, with the PubMed and Biblioteca Virtual em Saúde (BVS) portals as sources, under eligibility criteria: cross-sectional, cohort, case-control studies or case reports, published in Portuguese, English, French and Spanish, from 2015 to 2020. Studies that dealt with leprosy and tuberculosis not in the context of co-infection were excluded. The initial phase resulted in 1079 articles; 13 went on to a final stage. All were case reports. Thirteen (72.2\%) participants were male, aged between 17 and 72 years. Life habits were found in 8 (44.4\%) of the articles: 1 (12.5\%) reported chronic alcoholism, 1 (12.5\%) reported chronic smoking and alcoholism and 1(12.5\%) reported chronic smoking, alcoholism and use of illicit drugs. Pathological history was mentioned by $14(77.8 \%)$ patients; 1 (7.1\%) reported HIV/AIDS. Three patients (16.6\%) described previous history of tuberculosis and/or leprosy. Seven (38.9\%) participants reported vaccination with Bacillus Calmette-Guérin. The pulmonary form of tuberculosis predominated and one third of the patients presented resistance to, at least, one tuberculostatic. All cases had multibacillary leprosy. The study did not highlight any comorbidity, and there was no change in the course of the conditions owing to co-infection.
\end{abstract}

Key words: Leprosy; tuberculosis; co-infection; public health; systematic review.

J Infect Dev Ctries 2021; 15(11):1569-1577. doi:10.3855/jidc.14308

(Received 04 November 2020 - Accepted 09 May 2021)

Copyright (C) 2021 Cavalcante Trindade et al. This is an open-access article distributed under the Creative Commons Attribution License, which permits unrestricted use, distribution, and reproduction in any medium, provided the original work is properly cited.

\section{Introduction}

Leprosy and tuberculosis are contagious diseases endemic in several countries, both constituting an important public health problem in some of them. They are associated with unfavorable socioeconomic conditions and stigmatization, which have etiopathogenic and epidemiological similarities [1-4].

Leprosy is classified among neglected tropical diseases. ${ }^{5}$ It has the characteristic of being stigmatizing, due to skin and neurological impairment, and of bringing socioeconomic repercussions and damage to the patients life quality [5]. The World Health Organization (WHO), in the WHO Global Strategy for Leprosy 2016-2020, established as its main objective to reduce the global burden of the disease, that is, to reduce the number of new cases and, therefore, the number of people with disabilities [1]. About $94 \%$ of new cases of the disease are concentrated in countries like Bangladesh, Brazil, Congo, Ethiopia, India, Indonesia, Madagascar, Myanmar, Nepal, Nigeria, Philippines, Sri Lanka and Tanzania [1]. Brazil is responsible for the second largest absolute number of cases worldwide, and reported about 23,612 new cases of the disease in 2019 , which corresponded to $14.4 \%$ of global cases [1,5].

Tuberculosis is most common in pulmonary form, which facilitates the transmission in a favorable environment. Worldwide, in 2019, about 10 million people per year develop the disease. In 2020, 198 countries accounted for $99 \%$ of global cases [3]. In the WHO Global Strategy for Tuberculosis 2020, the main objective is to reduce the incidence of the disease by $80 \%$ by the year 2030 [3]. Brazil is among the 30 countries with higher incidence rates and, in 2019, diagnosed 73,864 new cases and, in 2018, registered 4,489 deaths from the disease $[3,4]$. The disease, in the country, affects more men and people aged 25 to 34 years of age. Locally, the greatest risk factors of illness are HIV/AIDS infection and the precarious economic conditions, with the incarcerated population, the homeless and indigenous people being the most affected groups [4]. 
The frequency of simultaneous occurrence of the two mycobacteriosis ranged from 2.5 e $13.5 \%$ in the studies developed in endemic areas to the two diseases, described by Rajagopala et al [6]. However, it is not possible to know the real prevalence of co-infection in Brazil. due to the lack of a corresponding epidemiological indicator $[2,7]$.

Inadequate socioeconomic situations favor both diseases and comorbidities related to immunosuppression, such as diabetes, malnutrition and HIV/AIDS, facilitate the development of tuberculosis [3]. On the other hand, vaccination with Bacillus Calmette-Guérin (BCG) seems to protect against the severe forms of the two infections [8,9]. Co-infection, however, remains with an uncertain pathophysiology, since it is not established whether the presence of one infection would protect against the other or, inversely, the host's immune response pattern would favor mycobacteriosis [6].

In the described context, it is reasonable to consider that simultaneous infection by the two mycobacteria may further characterize a public health problem, as it brings the risk of complications inherent to each disease separately, as well as the adverse effects of the drugs used in therapy, with clinical, economic and social repercussion. Despite this, there is no strategy to indicate the number of people who present the active diseases simultaneously, nor is there a public health policy for this specific population. Therefore, recognizing the relevance of this theme, the aim of this study was to describe the factors associated with the development of co-infection with leprosy and tuberculosis.

\section{Methodology}

A systematic review was carried out, taking as guideline the Preferred Reporting Items for Systematic Reviews and Meta-Analyses (PRISMA) and using PubMed data portals and Biblioteca Virtual em Saúde (BVS) as information sources [10].

The electronic search strategy started from the guiding question "What are the factors associated with leprosy and tuberculosis co-infection?". Medical Subject Heading (MeSH) keywords for the PubMed portal and combinations used for search were: "leprosy and tuberculosis" or "co-infection and leprosy and tuberculosis" or "leprosy and tuberculosis co-infection" or "tuberculosis and leprosy co-infection" or "coinfection and leprosy and tuberculosis and risk factors" or "leprosy and tuberculosis and risk factors" or "infections and leprosy and tuberculosis"or "leprosy and tuberculosis and epidemiological factors" or "leprosy and tuberculosis and health status indicators" or "leprosy and tuberculosis and cross protection" or "leprosy and tuberculosis and Bacillus Calmette Guerin Vaccine". In this portal, the filters "publication dates 5 years" and and Portuguese, English, French and Spanish languages were already used in the initial search; then, the same search was made for the year 2020.

For the BVS portal, the health descriptors of BVS (DeCs) and combinations were used: "leprosy and tuberculosis" or "leprosy and tuberculosis and coinfection" or "leprosy and tuberculosis co-infection" or "tuberculosis and leprosy co-infection" or "co-infection and leprosy and tuberculosis and risk factors" or "leprosy and tuberculosis and risk factors" or "infection and leprosy and tuberculosis" or "leprosy and tuberculosis and basic health indicators" or "crossprotection and leprosy and tuberculosis" or "leprosy and tuberculosis and epidemiological factors" or "BCG vaccine and leprosy and tuberculosis". In this phase, the filters were applied:"Portuguese, English, French and Spanish languages" and "years of publication from 2015 to 2020 ".

The eligibility criteria were: (a) cross-sectional studies, (b) longitudinal studies (cohort and casecontrol), (c) case reports, (d) articles published in Portuguese or English, from 2015 to 2020. Studies dealing with leprosy or tuberculosis singly were excluded.

In the screening phase, two independent reviewers, simultaneously, selected the studies to be used as data sources, based on the title and abstract. The selected articles were described in a spreadsheet according to the title, year of publication, type of study and results presented in the abstract. In this phase, duplicate articles that did not meet all the eligibility criteria were eliminated. When, by reading the title and the abstract, it was not possible for the reviewers to classify the article regarding eligibility, it was included for the next phase. Data collection in this phase took place in January and February 2020 and in March 2021.

The bibliographic search is shown in Figure 1 and was guided by the 2009 Prisma Diagram [11]. The screening phase of PubMed and BVS resulted in 936 and 143 articles, respectively. After eliminating duplicates and applying the inclusion criteria to the title and / or abstract, 18 were classified as eligible in PubMed and 15 in BVS. Crossing the two datebases, there were 9 duplicates, resulting in 24 eligible articles. 
Table 1. Characteristics of the studies and factors associated with leprosy and tuberculosis co-infection.

\begin{tabular}{|c|c|c|c|c|c|c|c|}
\hline Authors & $\begin{array}{l}\text { Year, type } \\
\text { of study }\end{array}$ & Gender/ age & $\begin{array}{l}\text { Comorbi-dities and } \\
\text { lifestyle habits }\end{array}$ & $\begin{array}{c}\text { Previous history of } \\
\text { leprosy or } \\
\text { tuberculosis }\end{array}$ & BCG vaccination & Family history & Contact \\
\hline $\begin{array}{c}\text { Sendrasoa et al } \\
{[13]}\end{array}$ & $\begin{array}{c}2015 \\
\text { Case report } \\
\text { English }\end{array}$ & $\begin{array}{c}\text { Male } \\
49 \text { years }\end{array}$ & $\begin{array}{c}\text { HIV negative } \\
\text { Denied smoking }\end{array}$ & $\begin{array}{c}\text { Denied a history of } \\
\text { tuberculosis }\end{array}$ & Affirmed & Not mentioned & Not mentioned \\
\hline $\begin{array}{l}\text { Ganesan and } \\
\text { Mandal [14] }\end{array}$ & $\begin{array}{c}2016 \\
\text { Case report } \\
\text { English }\end{array}$ & $\begin{array}{l}\text { Female } \\
45 \text { years }\end{array}$ & $\begin{array}{c}\text { HIV negative, no } \\
\text { venereal diseases } \\
\text { Did not mention } \\
\text { habits }\end{array}$ & $\begin{array}{l}\text { History of leprosy } \\
\text { (15 years earlier) }\end{array}$ & Not mentioned & Not mentioned & Not mentioned \\
\hline Dey et al [15] & $\begin{array}{c}2016 \\
\text { Case report } \\
\text { English }\end{array}$ & $\begin{array}{c}\text { Male } \\
29 \text { years }\end{array}$ & $\begin{array}{l}\text { HIV negative } \\
\text { Chronic alcoholic }\end{array}$ & Denied & Denied & Denied & Not mentioned \\
\hline Ghosh et al [16] & $\begin{array}{c}2017 \\
\text { Case report } \\
\text { English }\end{array}$ & $\begin{array}{c}\text { Male } \\
23 \text { years }\end{array}$ & $\begin{array}{l}\text { Denied diabetes or } \\
\text { hypertension } \\
\text { Denied use of illicit } \\
\text { drugs }\end{array}$ & Not mentioned & Not mentioned & Not mentioned & Not mentioned \\
\hline Gupta et al [17] & $\begin{array}{c}2017 \\
\text { Case report } \\
\text { English }\end{array}$ & $\begin{array}{l}\text { Male } \\
19 \text { years }\end{array}$ & $\begin{array}{l}\text { Did not mention } \\
\text { comorbidity or habits }\end{array}$ & $\begin{array}{l}\text { Past of tuberculosis } \\
\text { (5 years before) and } \\
\text { leprosy ( } 6 \text { years } \\
\text { before). }\end{array}$ & Not mentioned & Not mentioned & Not mentioned \\
\hline $\begin{array}{c}\text { Branagam et al } \\
{[18]}\end{array}$ & $\begin{array}{c}2017 \\
\text { Case report } \\
\text { English }\end{array}$ & $\begin{array}{l}\text { Male } \\
17 \text { years }\end{array}$ & $\begin{array}{l}\text { HIV negative } \\
\text { Denied smoking }\end{array}$ & $\begin{array}{l}\text { Brother had treated } \\
\text { Isoniazid-resistant } \\
\text { tuberculosis a year } \\
\text { earlier }\end{array}$ & Not mentioned & Not mentioned & Not mentioned \\
\hline $\begin{array}{c}\text { Mangum et al } \\
{[19]}\end{array}$ & $\begin{array}{c}2018 \\
\text { Case report } \\
\text { and litera- } \\
\text { ture review } \\
\text { English }\end{array}$ & $\begin{array}{c}\text { Female } 32 \\
\text { years }\end{array}$ & Not mentioned & Not mentioned & Not mentioned & Not mentioned & Not mentioned \\
\hline $\begin{array}{l}\text { Robinet et al } \\
{[20]}\end{array}$ & $\begin{array}{l}2018 \\
\text { Case report } \\
\text { Spa-nish }\end{array}$ & $\begin{array}{c}\text { Male } \\
35 \text { years black } \\
\text { skin }\end{array}$ & $\begin{array}{c}\text { Denied comorbidities } \\
\text { Did not mention } \\
\text { habits }\end{array}$ & Not mentioned & Not mentioned & Denied & Not mentioned \\
\hline Shetty et al [21] & $\begin{array}{c}2018 \\
\text { Case report } \\
\text { English }\end{array}$ & $\begin{array}{c}\text { Female } 57 \\
\text { years }\end{array}$ & $\begin{array}{c}\text { Denied comorbidi- } \\
\text { ties } \\
\text { Did not mention } \\
\text { habits }\end{array}$ & Denied & Affirmed & Not mentioned & Not mentioned \\
\hline Kama et al [22] & $\begin{array}{c}2019 \\
\text { Case report } \\
\text { English }\end{array}$ & $\begin{array}{c}\text { Male } \\
25 \text { years }\end{array}$ & $\begin{array}{l}\text { Did not mention } \\
\text { comorbidity or habits }\end{array}$ & Denied both & Not mentioned & Not mentioned & $\begin{array}{c}\text { Positive ( } 2 \text { people } \\
\text { with resistant } \\
\text { tuberculosis) }\end{array}$ \\
\hline Singh [23] & $\begin{array}{l}2019 \\
\text { Case report } \\
\text { English }\end{array}$ & $\begin{array}{c}\text { Male } \\
30 \text { years }\end{array}$ & $\begin{array}{l}\text { HIV negative } \\
\text { Did not mention other } \\
\text { comorbidity or habits }\end{array}$ & Not mentioned & Not mentioned & Not mentioned & Not mentioned \\
\hline \multirow{6}{*}{$\begin{array}{c}\text { Keragala et al } \\
{[24]}\end{array}$} & \multirow{6}{*}{$\begin{array}{c}2020 \\
\text { Case report } \\
\text { English }\end{array}$} & $\begin{array}{l}\text { Female, } 57 \\
\text { years }\end{array}$ & $\begin{array}{l}\text { Denied diabetes or } \\
\text { hypertension }\end{array}$ & $\begin{array}{c}\text { Ganglio-nic } \mathrm{Tb} \text { in } \\
\text { the past }\end{array}$ & BCG positive & Not mentioned & Denied \\
\hline & & $\begin{array}{c}\text { Female, } 47 \\
\text { years }\end{array}$ & $\begin{array}{l}\text { Denied smoking and } \\
\text { alcoholic }\end{array}$ & Not mentioned & BCG positive & Not mentioned & Denied \\
\hline & & $\begin{array}{c}\text { Male } \\
72 \text { years }\end{array}$ & $\begin{array}{c}\text { Denied comorbidi- } \\
\text { ties } \\
\text { HIV negative } \\
\text { Smoking and }\end{array}$ & Not mentioned & BCG positive & Not mentioned & Denied \\
\hline & & $\begin{array}{c}\text { Male } \\
59 \text { years }\end{array}$ & $\begin{array}{l}\text { alcoholic in the past } \\
\text { Denied comorbidi- } \\
\text { ties } \\
\text { Reported smoking } \\
\text { and alcoholic }\end{array}$ & Not mentioned & Not mentioned & Not mentioned & Denied \\
\hline & & $\begin{array}{l}\text { Male } \\
54 \text { years }\end{array}$ & $\begin{array}{c}\text { Denied diabetes, HIV } \\
\text { negative } \\
\text { Reported use illicit } \\
\text { drug, smoking and } \\
\text { alcoholic }\end{array}$ & Not mentioned & BCG positive & Not mentioned & Daughter had MH \\
\hline & & $\begin{array}{c}\text { Male } \\
50 \text { years }\end{array}$ & $\begin{array}{l}\text { Denied diabetes } \\
\text { HIV negative }\end{array}$ & Not mentioned & BCG positive & Not mentioned & Denied \\
\hline $\begin{array}{c}\text { Rousset et al } \\
{[25]}\end{array}$ & $\begin{array}{c}2020 \\
\text { Case report } \\
\text { French }\end{array}$ & $\begin{array}{c}\text { Male } \\
34 \text { years }\end{array}$ & Not mentioned & Not mentioned & $\begin{array}{l}\text { Reported not } \\
\text { knowing }\end{array}$ & Not mentioned & Not mentioned \\
\hline
\end{tabular}


In the eligibility phase, the following were excluded: 6 due to the type of study - for being a systematic review or opinion article; 4 did not characterize co-infection; 1 case report article, whose case was repeated by the same authors in a case series publication included for the next phase. Therefore, 13 articles were selected for the final stage of the study.

In the data extraction phase, the included articles were read and arranged in a spreadsheet, using the variables: author and year of publication, language of publication, type of study, number of participants and main conclusions. The variables considered as possible facilitating co-infection factors were: socio-economicdemographic data, use of immunosuppressive medications, BCG vaccine, comorbidities, lifestyle, cases of leprosy and or tuberculosis in the family, contact with leprosy and or tuberculosis patients, previous history of leprosy and or of tuberculosis, clinical form of leprosy and tuberculosis, complications of leprosy and tuberculosis.

The methodological evaluation of the articles was carried out using the Care Report Guidelines (CARE) instrument, which adopts the following list of items to be verified: title, keywords, abstract, introduction, patient data, clinical findings, schedule, diagnostic evaluation, therapeutic interventions, monitoring and results, discussion, patient's perspective and informed consent [12]. The studies were grouped according to the percentage of positive responses to the applicable items, but no article was eliminated for its quality.

\section{Results}

The selected articles - according to the established eligibility criteria -, and analyzed, after completing the review phases, are presented in Tables 1 and 2. All were case report studies; one of the articles was a case series, in a total of 18 patients [13-30].

The factors considered to be related to co-infection are shown in Table 1. In the sociodemographic variables, 13 (72.2\%) studies reported case of a male participant. The patients age ranged from 17 to 72 years (mean of 31.5 and median of 34.5 years). Only 1 (5.6\%) article referred to the participant's race, described as black. No study made reference to the profession or other socioeconomic data. As for the patient's country of residence, $6(33,3 \%)$ were from India, $6(33.3 \%)$ from Sri-lanka, $1(5.6 \%)$ from Madagascar, $1(5.6 \%)$ from the United States, 1 (5.6\%) from Congo, 1 (5.6\%) from Papua New Guinea, 1 (5.5\%) from East Timor, 1 $(5.5 \%)$ from France.

The habits and customs of the participant of each study were described in $8(44.4 \%)$ of the articles; 2
Figure 1. Flowchart of identification and selection of articles.

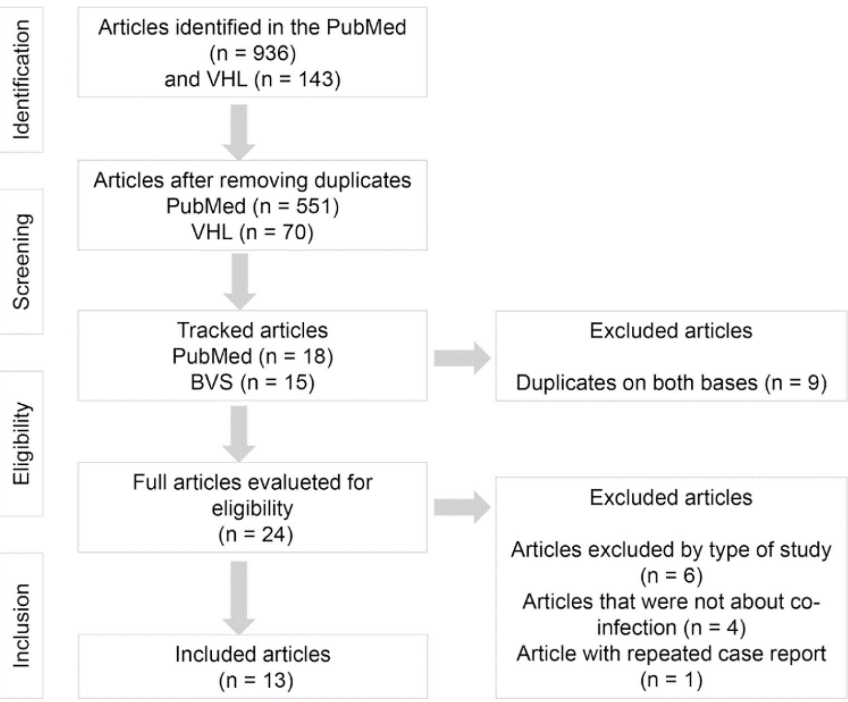

The figure summarizes the bibliographic search and the systematic methodology following PRISMA [11]

(11.1\%) denied smoking, 1 (5.6\%) referred chronic alcoholism, 1 (5.6\%) denied the use of illicit drugs, 1 (5.6\%) denied alcoholism and smoking, 1 (5.5\%) referred alcoholism and smoking in the past, 1 (5.5\%) described smoking and social drinking, 1 (5.5\%) referred the use of illicit drugs, alcoholism and smoking. The pathological personal history was mentioned in $14(77.8 \%)$ of the cases: $4(22.2 \%)$ referred HIV negative; 1 (5.5\%) described negative sorology for HIV and venereal disease, 1 (5.6\%) reported HIV positive serology, 1(5.6\%) denied diabetes and hypertension, $1(5.6 \%)$ reported diabetes and denied HIV/AIDS, 2 (11.1\%) denied diabetes and HIV/AIDS, $4(22.2 \%)$ denied comorbidities. One $(5.6 \%)$ participant had a previous history of tuberculosis and leprosy, $1(5.5 \%)$ of leprosy and 1 $(5.6 \%)$ of tuberculosis. Ten $(55.6 \%)$ participants referred to vaccination for Bacillus Calmette-Guérin (BCG), being positive for 7 (38.9\%) of them, negative for $1(5.6 \%)$ and unknown for $2(11.1 \%)$ pacients. Regarding to the epidemiological history, 2 (11.1\%) reported contact with people with tuberculosis, being 1 $(5.6 \%)$ of them with his brother; the daughter of 1 (5.6\%) patient had leprosy; 5 (27.8\%) participants denied any contact with people with leprosy or tuberculosis.

The findings related to leprosy and tuberculosis are shown in Table 2, along with the methodological quality and the conclusions of each study. No patient had an atypical evolution of the conditions. Two $(11.1 \%)$ participants progressed to death due to 
tuberculosis. Other complications presented were inherent to each disease, such as leprosy reactions and neuritis - which occurred in $10(55.6 \%)$ and $4(22.2 \%)$ participants, respectively; 1 (5.6\%) patient had a reaction to tuberculostatic medication; and $1(5.6 \%)$ patient had a deficiency of the enzyme 6 phosphate- glucose-dehydrogenase (G-6-PD) and received the modified leprosy multidrug therapy scheme (MDT).

Eleven $(61.1 \%)$ pacientes was affected by the pulmonary form, followed by the ganglionic and cutaneous varieties, which affected $3(16.7 \%)$ and 2 $(11.1 \%)$ of the participants respectively; 1 (5.6\%)

Table 2. Characteristics of leprosy and tuberculosis, conclusions and methodological evaluation of each study.

\begin{tabular}{|c|c|c|c|c|}
\hline Authors & Information about leprosy & $\begin{array}{c}\text { Information about } \\
\text { tuberculosis }\end{array}$ & Main conclusions & $\begin{array}{l}\text { Positivity on the } \\
\text { CARE Check list }\end{array}$ \\
\hline Sendrasoa et al [13] & Virchowian leprosy & Pulmonary tuberculosis & $\begin{array}{l}\text { Co-infection case that received specific } \\
\text { treatment for both conditions and evolved } \\
\text { well. }\end{array}$ & $63 \%$ \\
\hline $\begin{array}{l}\text { Ganesan and Mandal } \\
\text { [14] }\end{array}$ & $\begin{array}{l}\text { Virchowian leprosy and type } 2 \\
\text { reaction. Positive bacilloscopy. } \\
\text { No disabilities. }\end{array}$ & $\begin{array}{c}\text { Primary tuberculosis in the } \\
\text { tongue. }\end{array}$ & $\begin{array}{c}\text { Co-infection case that received specific } \\
\text { treatment for both conditions and evolved } \\
\text { well. }\end{array}$ & $70 \%$ \\
\hline Dey B et al [15] & $\begin{array}{c}\text { Virchowian dimorphic leprosy } \\
\text { and type } 2 \text { reaction. Positive } \\
\text { bacilloscopy; neuritis } \\
\text { (auricular, peroneal and tibial } \\
\text { posterior) }\end{array}$ & $\begin{array}{l}\text { Ankle verrucous } \\
\text { tuberculosis }\end{array}$ & $\begin{array}{l}\text { Co-infection case that received specific } \\
\text { treatment for both conditions and evolved } \\
\text { well. }\end{array}$ & $75 \%$ \\
\hline Ghosh et al [16] & Tuberculoid dimorphic leprosy & Cutaneous tuberculosis & $\begin{array}{l}\text { Foot ulcer considered leprosy and cutaneous } \\
\text { tuberculosis. }\end{array}$ & $83 \%$ \\
\hline Gupta R et al [17] & $\begin{array}{c}\text { Dimorphic leprosy and reverse } \\
\text { reaction }\end{array}$ & $\begin{array}{l}\text { Multidrug-resistant } \\
\text { pulmonary tuberculosis }\end{array}$ & $\begin{array}{c}\text { Co-infection case that received specific } \\
\text { treatment for both conditions and evolved } \\
\text { well. }\end{array}$ & $64 \%$ \\
\hline Branagam P et al [18] & $\begin{array}{c}\text { Plaques and nodules on tattoo } \\
\text { (multibacillary leprosy); ulnar } \\
\text { neuritis }\end{array}$ & $\begin{array}{l}\text { Isoniazid-resistant } \\
\text { pulmonary tuberculosis }\end{array}$ & $\begin{array}{l}\text { Co-infection case that received specific } \\
\text { treatment for both conditions; modified } \\
\text { multidrug therapy; evolved well, but } \\
\text { persisted with sequel in limb. The authors } \\
\text { suggest that there may have been a } \\
\text { paradoxical immune reconstitution after } \\
\text { starting tuberculosis treatment. }\end{array}$ & $58 \%$ \\
\hline Mangum L et al*[19] & $\begin{array}{c}\text { Multibacillary leprosy } \\
\text { diagnosed due to hand finger } \\
\text { osteomyelitis }\end{array}$ & Pulmonary tuberculosis & $\begin{array}{l}\text { Good evolution after specific therapies. The } \\
\text { authors suggest that corticosteroid therapy } \\
\text { facilitates the development of latent } \\
\text { tuberculosis and that active tuberculosis } \\
\text { should be avoided before considering false } \\
\text { positive tests for this disease. }\end{array}$ & $67 \%$ \\
\hline Robinet et al [20] & Dimorphic leprosy & Ganglionic tuberculosis & $\begin{array}{l}\text { Co-infection case that received specific } \\
\text { treatment for both conditions and evolved } \\
\text { well. }\end{array}$ & $50 \%$ \\
\hline Shetty et al [21] & $\begin{array}{c}\text { Multibacillary leprosy, eritema } \\
\text { nodoso, neuritis }\end{array}$ & Pulmonary tuberculosis & $\begin{array}{l}\text { Concomitant diagnosis. } \\
\text { Patient follow-up was lost. }\end{array}$ & $83 \%$ \\
\hline Kama G et al $[22]$ & $\begin{array}{l}\text { Multibacillary leprosy, ulnar } \\
\text { and peroneal neuritis }\end{array}$ & $\begin{array}{l}\text { Ganglionic tuberculosis, } \\
\text { positive rapid test for } \\
\text { multidrug-resistant } \\
\text { tuberculosis }\end{array}$ & $\begin{array}{l}\text { Co-infection case that received specific } \\
\text { treatment for both conditions; there was an } \\
\text { exchange of tuberculostatic drugs; evolved } \\
\text { well. }\end{array}$ & $67 \%$ \\
\hline Singh $[23]$ & $\begin{array}{l}\text { Virchowian leprosy and type } 2 \\
\text { reaction. }\end{array}$ & Pulmonary tuberculosis & $\begin{array}{l}\text { Concomitant diagnosis. Co-infection case } \\
\text { that received specific treatment for both } \\
\text { conditions and evolved well. }\end{array}$ & $58 \%$ \\
\hline Keragala et al [24] & $\begin{array}{l}\text { Tuberculoid dimorphic } \\
\text { leprosy, } \\
\text { reverse reaction and neurit } \\
\text { Tuberculoid dimorphic }\end{array}$ & Disseminated tuberculosis & $\begin{array}{l}\text { Concomitant diagnosis. Co-infection case } \\
\text { that received specific treatment for both } \\
\text { conditions and evolved well. }\end{array}$ & $70 \%$ \\
\hline \multirow{6}{*}{ Keragala et al [24] } & $\begin{array}{l}\text { leprosy, } \\
\text { reverse reaction }\end{array}$ & Pulmonary tuberculosis & Leprosy was diagnosed first; good evolution. & \multirow{6}{*}{$92 \%$} \\
\hline & Virchowian leprosy & Pulmonary tuberculosis & $\begin{array}{l}\text { Leprosy was diagnosed first; passed away } \\
\text { due to } \mathrm{Tb} \text {. }\end{array}$ & \\
\hline & Virchowian leprosy & Pulmonary tuberculosis & $\begin{array}{c}\text { Concomitant diagnosis; unreported } \\
\text { evolution. }\end{array}$ & \\
\hline & Virchowian dimorphic leprosy & Pulmonary tuberculosis & $\begin{array}{c}\text { Concomitant diagnosis; unreported } \\
\text { evolution. }\end{array}$ & \\
\hline & Virchowian dimorphic leprosy & Pulmonary tuberculosis & $\begin{array}{c}\text { Leprosy was diagnosed first; passed away } \\
\text { due to } \mathrm{Tb} \text {. }\end{array}$ & \\
\hline & $\begin{array}{l}\text { Virchowian leprosy and type } 2 \\
\text { reaction. }\end{array}$ & Ganglionic tuberculosis & $\begin{array}{l}\text { Leprosy was diagnosed first; unreported } \\
\text { evolution. }\end{array}$ & \\
\hline
\end{tabular}


patient had primary tuberculosis on the tongue and 1 $(5.5 \%)$ had diffuse tuberculosis. Four (22.2\%) participants resisted at least one tuberculostatic agent.

Seventeen (94.4\%) patients developed a multibacillary operational form, 8 (47.1\%) being clinically classified as dimorphic and $6(35,3 \%)$ as virchowian; $3(17.6 \%)$ did not receive a clinical classification. One $(5.6 \%)$ participant received no description of the clinical form, but the administrated therapy was also multibacillary. Ten $(55.6 \%)$ patients had a leprosy reaction, $5(27.8 \%)$ in the form of erythema nodosum, $4(22.2 \%)$ of neuritis (being 2 concomitantly with another reaction) and $3(16.7 \%)$ of reverse reaction.

Tuberculosis was diagnosed first in $3(16.7 \%)$ cases and leprosy in $6(33.3 \%)$. There was a concomitant diagnosis in $7(38.9 \%)$ cases and in $2(11.1 \%)$ studies the information did not appear.

\section{Discussion}

This review analyzed publications on leprosy and tuberculosis coinfection, aiming to identify factors that could be related to the simultaneous occurrence of diseases. However, all of the selected studies were case reports, so it would not be appropriate to assess their statistical power.

No patient had an atypical evolution of the conditions. The complications presented were inherent to each disease, such as leprosy reactions and reaction to tuberculostatic drugs. There was a predominance of pulmonary tuberculosis; about one quarter of the patients had resistance to at least one tuberculostatic. All had multibacillary leprosy. The vast majority of the articles reported cases of young male patients. There was no emphasis on other sociodemographic variables, comorbidities or lifestyle habits.

Environmental and genetic factors seem to influence the infection susceptibility and the development of both leprosy and tuberculosis [31]. However, the interaction of the diseases in the same host is uncertain. Paleontological studies of ancient European populations, using molecular biology techniques, suggest that co-infection ceased to exist among indigenous populations as effect of natural genetic selection, supposing that tuberculosis had caused the death of the co-infected [32]. Cardenas et al. (2016) performed a study to test Chaussinand's (1948) hypothesis that there would be cross-immune protection that would make it difficult for the diseases to coexist; the results, based on serological tests of 25 volunteers, supported the existence of cross-immunity between mycobacteria $[33,34]$. In this context, Trindade et al.
(2013) suggest that there has been a decrease in coinfection in Brazil in the last decades as outcome of $B C G$ vaccination [35].

Although the present study identified a high percentage of co-infection in male and young individuals, the reduced absolute number of participants did not allow a statistical analysis of cause and effect. In addition, in the national and global panorama, young men constitute the most affected group by both leprosy and tuberculosis [1-4]. However, in a literature review of 156 patients who developed leprosy and tuberculosis, Rajagopala et al. (2012) also reported that males were the most affected $(81.3 \%)$, but those affected were older, with an average age of 37.8 years. In that study, $3.9 \%$ of patients developed the infections simultaneously and $90.4 \%$ had leprosy first; the interval between the onset of infections ranged from 1 month to 25 years (median 1.5 years) [6].

With regard to the clinical profile of patients and the evolution of diseases in the present study, there was no highlight for any comorbidity, as well as there was no change in the course of the conditions as consequence of co-infection. In this sense, Rajagopala et al. (2012) found as comorbidities in patients who developed both diseases simultaneously: rheumatoid arthritis and use of immunosuppressive medications, use of corticosteroids and immunobiologicals; transplantation and immunosuppression and HIV/AIDS [6].

As for tuberculosis, there was no highlight for any clinical pattern, with different forms of the disease being reported, including a rare oral presentation [36]. However, it should be noted that one third of the cases showed resistance to one or multiple tuberculostatic agents. Drug resistance in tuberculosis is a challenging reality, presented in the form of monoresistance (resistance to Rifampicin), multiresistance (resistance to Rifampicin and Isoniazid) and extensive resistance (resistance to multiple drugs). It is more common in retreatment situations - mainly related to treatment abandonment - than in primary forms and is considered a cause of worsening morbidity [3,37]. In a scenario of co-infection, Trindade et al. (2013) and Rajagopala et al. (2012) warn about the consequence of an active tuberculosis going unnoticed in a leprosy patient, which can stimulate the development of drug resistance, through the use of Rifampicin alone [6,35].

About leprosy, it is noteworthy that all patients in the study had a multibacillary form and that most of them were in leprosy reaction. The relation of the multibacillary pole of leprosy and tuberculosis seems to be result of the immune response pattern developed by these patients, of Th2 type, with a predominance of 
interleukin production, inhibiting intracellular response, necessary to destroy mycobacteria [38]. However, in a literature review, Rawson et al. (2014) reported that tuberculosis occurred in leprosy patients not only in multibacillary forms, but in its various clinical forms, as well as type I and type II leprosy reactions also occurred in these patients [39].

Leprosy reactions can be type I - reverse reaction and neuritis - and type II - which has erythema nodosum as its most common form. They are frequent in leprosy patients, particularly in multibacillary forms, and occur in consequence to an exacerbated inflammatory process of uncertain etiopathogenesis. They are associated with an increase in leprosy morbidity, not only for the inflammation and its consequences, but also for the adverse effects of the medications used to control it [40]. Stimulating co-infection in the presence of leprosy reactions could be related to the prolonged use of corticosteroids in therapy, which would make patients with latent tuberculosis susceptible to developing the disease, especially in the pulmonary form. However, despite the recognition of conditions predisposing to the occurrence of tuberculosis, such as diabetes mellitus, HIV/AIDS and the use of immunosupressive drugs, the influence of corticosteroid therapy is controversial. Jick et al. (2006), in a case-control study, found that patients using glucocorticoids show increased risk for developing tuberculosis [41]. Rawson et al. (2014), in a survey carried out for 10 years in India, described the occurrence of only three cases of co-infection. Although two of these three patients were on corticosteroid therapy, a much higher number of simultaneous occurrences of diseases would be expected, since that country has a high incidence of both tuberculosis and leprosy - and, certainly, with many patients using corticosteroids for leprosy reactions [39].

On the other hand, even though leprosy reactions have an uncertain etiology, it is considered that other foci of infection may serve as a trigger for the exacerbated inflammatory response. Thus, as most patients in the study experienced a reaction, it would be reasonable to accept tuberculosis as a possible predisposing factor [42].

The limitations of this study are related to the small number of selected articles and, therefore, the clinical or lifestyle factors described were not statistically relevant. In addition, as previously cited, all selected articles were case reports; no analytical study that allowed to identify risk or association factors, such as case-control or cohort, was found. The evaluation of the methodological quality of the articles had its own limitation, since the instructions to the researchers vary according to each publication journal and, also, by the instrument used - the CARE -, to represent the opinion of its authors.

\section{Conclusions}

Despite the fact that the present review found and selected a small number of studies, the predominance of co-infection in young men, with multibacillary leprosy and in reaction, with varied clinical forms of tuberculosis was highlighted. There were no complications of any of the diseases or an increase in morbidity. It is noteworthy that one third of the patients had a form of drug resistance to at least one tuberculostatic. Co-infection with leprosy and tuberculosis needs to be better identified, given the possibility of stimulating drug resistance if tuberculosis goes unnoticed, just as tuberculosis can be a stimulus to leprosy reaction. New studies on this theme may help to unveil this and other associations, just as the creation of an indicator of co-infection of leprosy and tuberculosis in endemic countries could guide managers in making decisions related to these health problems.

\section{References}

1. World Health Organization (WHO) (2016) Global Leprosy Estrategy 2016-2020. Operational Manual. Available https://www.paho.org/en/documents/global-leprosy-strategy2016-2020-operational-manual. Accessed: 15 january 2020.

2. Ministry of Health (Ministério da Saúde, MS) (2021) Epidemiological indicators for monitoring leprosy. Indicators to assess the quality of leprosy services. Leprosy 2021. Special Epidemiological Bulletin. Appendices. Available: http://www.aids.gov.br/pt-br/pub/2021/boletimepidemiologico-hanseniase-2021. Accessed: 28 march 2021. [Available in Portuguese]

3. World Health Organization (WHO) (2020) Global tuberculosis report $2020 . \quad$ Available: https://apps.who.int/iris/bitstream/handle/10665/336069/9789 240013131-eng.pdf. Accessed: 28 march 2021.

4. Ministry of Health (Ministério da Saúde, MS) (2021) Tuberculosis 2021. Special Tuberculosis Epidemiological Bulletin 2021. Available: https://www.gov.br/saude/ptbr/media/pdf/2021/marco/24/boletim-tuberculose-

2021 24.03. Accessed: 28 march 2021. [Available in Portuguese]

5. World Health Organization (WHO) (2019) Global leprosy (Hansen disease) update, 2019: time to step-up prevention initiatives. Weekly epidemiological record. 4 september 2020 , 95th year, no 36, 2020, 95, 417-440. Available: https://reliefweb.int/report/world/weekly-epidemiologicalrecord-wer-4-september-2020-vol-95-no-36-pp-417-440-enfr. Accessed: 28 march 2021.

6. Rajagopala S, Devaraj U, D'Souza G, Aithal VV (2012) Coinfection with $M$. tuberculosis and M. leprae: case report and systematic review. J Mycobact Dis 2: 1000118. 
7. Ministry of Health (Ministério da Saúde, MS) (2020) Panorama of tuberculosis in Brazil: epidemiological and operational indicators Secretariat of Health Surveillance. Available: http://www.aids.gov.br/pt-br/pub/2019/panoramada-tuberculose-no-brasil-indicadores-epidemiologicos-eoperacionais. Accessed: 28 march 2020. [Available in Portuguese]

8. Duppre NC, Camacho LAB, Cunha SS da, Struchiner CJ, Sales AM, Nery JAC, Sarno EM (2008) Effectiveness of BCG vaccination among leprosy contacts: a cohort study. Trans $\mathrm{R}$ Soc Trop Med Hyg 102: 631-638.

9. Mangtani P, Abubakar I, Ariti C, Beynon R, Pimpin L,Fine PEM, Rodrigues LC, Smith PG, Lipman M, Whiting FP, Sterne JA (2014) Protection by BCG vaccine against tuberculosis: a systematic review of randomized controlled trials. Clin Infect Dis 58: 470-480.

10. Enhancing the QUAlity and Transparency Of health Research (Equator network) (2020) The PRISMA 2020 statement: an updated guideline for reporting systematic reviews. Available: https://www.equator-network.org/reportingguidelines/prisma/ Accessed: 15 january 2020.

11. PRISMA (2009) PRISMA Flow diagram. Available: http://prisma-

statement.org/prismastatement/flowdiagram.aspx. Accessed: 15 january 2020.

12. Enhancing the QUAlity and Transparency Of health Research (Equator network) (2020) The CARE guidelines: consensusbased clinical case reporting guideline development. Available: https://www.equator-network.org/reportingguidelines/care/. Accessed: 15 january 2020.

13. Sendrasoa FA, Ranaivo IM, Raharolahy O, Andrianarison M, Ramarozatovo LS, Rapelanoro Rabenja FR (2015) Pulmonary tuberculosis and lepromatous leprosy coinfection. Case Rep Dermatol Med 2015: 898410.

14. Ganesan V, Mandal J (2016) Primary oral tuberculosis in a patient with lepromatous leprosy: Diagnostic dilema. Int $\mathrm{J}$ Mycobacteriol 5: $102-105$.

15. Dey B, Gochhait D,1 Prabhakaran N, Chandrashekar L, Behera B (2016) A rare case of coexistence of borderline lepromatous leprosy with tuberculosis verrucosa cutis. Case Rep Infect Dis 2016: 1746896.

16. Ghosh R, Barua JK, Garg A, Barman BP (2017) Dual infection with mycobacterium tuberculosis and mycobacterium leprae at same site in an immunocompetent patient: an unusual presentation. Indian J Dermatol 62: 548.

17. Gupta R, Garg K, Bhalla M, Janmeja AK (2017) Multidrugresistant tuberculosis and leprosy: an unsolved Mystery. Lung India 34: 364-367

18. Branagan P, Moran B, Fitzgibbon M, Reid V, McMenamin M, Kane M, Kelly F, Barnes L, McLaughlin A, Keane J (2016) Inoculation site leprosy in a tattoo as a paradoxical reaction following tuberculosis treatment. Int J Tuberc Lung Dis 20: 706-708

19. Mangum L, Kilpatrick D, Stryjewska B, Sampath R (2018) Tuberculosis and leprosy coinfection: a perspective on diagnosis and treatment. Open Forum Infect Dis 5: ofy133.

20. Robinet MET, Rodríguez HM, Pupo NL (2018) Leprosy and ganglionar tuberculosis coinfection in an adult. Medisan 22: 559-566 [Article in Spanish].

21. Shetty S, Umakanth S, Manandhar B, Nepali PB (2018) Coinfection of leprosy and tuberculosis. BMJ Case Rep 2018: bcr-2017-222352.
22. Kama G, Huang GKL, Taune M, Arura R, Morris L, Kombuk B, Marome A, O'Brien DP (2019) Tuberculosis treatment unmasking leprosy: management of drug-resistant tuberculosis and leprosy co-infection. Public Heath Action 9 Suppl 1: S83S85.

23. Singh R (2019) Tuberculosis and leprosy co-infection. Inn J Med Health Sci 9: 535-537.

24. Keragala BSDP, Herath HMMTB, Janapriya GHDC, Vanitha S, Balendran T, Janani T, Keragala TS, Gunasekera CN (2020) Coexistence of mycobacterial infections - Mycobacterium tuberculosis and Mycobacterium leprae - in Sri Lanka: a case series. J Med Case Rep 14: 101.

25. Rousset L, Sokal A, Vignon-Pennamen M-D, Pagis V, Rybojad M, Lecorche E, Mougari F, Bagot M, Bouaziz J-D, Jachiet M (2020) Association of borderline tuberculoid leprosy and tuberculosis: a case report and review of the literature. Ann Dermatol Venereol 147: 886-891 [Article in French].

26. Dallmann-Sauer M, Correa-Macedo W, Schurr E (2018) Human genetics of mycobacterial disease. Mamm Genome 29: 523-538.

27. Donoghue HD (2019) Tuberculosis and leprosy associated with historical human population movements in Europe and beyond - an overview based on mycobacterial ancient DNA. Ann Hum Biol 46: 120-128.

28. Cardenas VM, Orloff MS, Kaminaga J, Cardenas IC, Brown J, Hainline-Williams S, Duthie MS, Gonzalez-Puche AC, Mukasa L, Patil N, Mcelfish PA, Bates JH (2016) Tuberculosis and leprosy infections in the Marshallese population of Arkansas, USA. Lepr Rev 87: 109-112.

29. Chaussinand R (1948) Tuberculosis and leprosy, antagonistic diseases. Prevention of leprosy by tuberculosis. Int J Lepr 16: 431-438.

30. Trindade MAB, Miyamoto D, Benard G, Sakai-Valente NY, Vasconcelos DM, Naafs B (2013) Lepros and tuberculosis coinfection: clinical and immunological report of two cases and review of the literature. Am J Trop Med Hyg 88: 236-240.

31. Jain P, Jain I. Oral (2014) Manifestations of tuberculosis: step towards early diagnosis. J Clin Diagn Res 8: ZE18-ZE21.

32. Steingart KR, Schiller I, Horne DJ, Pai M, Boehme CC, Dendukuri N (2014) Xpert ${ }^{\circledR}$ MTB/RIF assay for pulmonary tuberculosis and rifampicin resistance in adults. Cochrane Database Syst Rev 2014: CD009593.

33. Mesquita Júnior D, Araújo JAP, Catelan TTT, Souza AWS, Cruvinel WM, Andrade LEC, Silva NP (2010) Immune System - Part II Basis of the immunological response mediated by $\mathrm{T}$ and B lymphocytes. Bras J Rheumatol 50: 552-80.

34. Rawson TM, AnjumV, Hodgson J, Rao AK, Murthy K, Rao PSSS, Subbanna J, Rao PVR (2014) Leprosy and tuberculosis concomitant disease. Lepr Rev 85: 288-295.

35. Teixeira MAG, Silveira VM, França ER (2010) Characteristics of leprosy reactions in paucibacillary and multibacillary individuals attended at two reference centers in Recife, Pernambuco. Rev Soc Bras Med Trop 43: 287-292. [Article in Portuguese]

36. Jick SS, Lieberman ES, Rahman MU, Choi HK (2006) Glucocorticoid use, other associated factors and the risk of tuberculosis. Arthritis Care Res 55: 19-26.

37. Scollard DM, Smith T, Bhoopat L, Theetranont C, Rangdaeng S, Morens DM (1994) Epidemiologic characteristics of leprosy reactions. Int J Lepr Other Mycobact Dis 62: 559-567. 


\section{Corresponding author}

Professor Luciana Cavalcante Trindade, MD

ABC Medical School, Stricto Sensu Postgraduate Program in Health Sciences, Santo André, Rua Aderbal Maia Paiva, 600,

Portal do Sol, João Pessoa/PB, CEP 58046527

Phone: +5583993820781

Fax: +5583993820781

Email: trindadeluc@gmail.com

Conflict of interests: No conflict of interests is declared. 